\title{
Comparative Studies on the Agglutination of Fowl Red Blood Cells by the Haemag- glutinins of Vaccinia and Coxsackie A 7 Viruses
}

\author{
By J. D. WILLIAMSON* \\ Viral Epidemiology Unit of the University of Glasgow, \\ Ruchill Hospital, Glasgow, Scotland
}

(Received 18 April 1966)

\begin{abstract}
SUMMARY
Red blood cells from a group of fowls were sensitive to the haemagglutinins of vaccinia and Coxsackie Ar viruses but the red cells from certain fowls exhibited differences in their relative sensitivities. Differences between the reaction of these haemagglutinins with susceptible red cells of the same sensitivity were shown by treatment with chemical and physical agents. There were differences in the effect of $\mathrm{pH}$ value on the haemagglutination titres and, unlike Coxsackie A7 haemagglutinin, the adsorption of vaccinia haemagglutinin to susceptible red cells was inhibited by divalent cations. Red cell receptors for both haemagglutinins were insensitive to RDE (receptor destroying enzyme) but were inactivated by treatment with potassium periodate, papain or $\alpha$-chymotrypsin. There were quantitative differences in the degrees or rates of receptor destruction by these reagents. Haemagglutination by vaccinia and Coxsackie $\mathrm{Ar}$ haemagglutinins was inhibited only by homologous antiserum. These qualitative and quantitative differences indicate separate red cell receptors for the two haemagglutinins.
\end{abstract}

\section{IN'TRODUCTION}

Red blood cells from certain fowls are highly susceptible to agglutination by the haemagglutinin specifically associated with vaccinia-infected tissue. Other fowls and most other animals possess red cells which are either agglutinated to a much decreased titre or are completely insensitive (Clark \& Nagler, 1943; Burnet \& Boake, 1946). Fowl red cells which are agglutinable by the vaccinia haemagglutinin show a parallel sensitivity to agglutination by normal tissue lipids (Burnet \& Stone, 1946). Physicochemical studies have shown that vaccinia haemagglutinin is particulate and distinct from the infective particle (Chu, 1948; Neff, Ackermann \& Preston, 1965). The activity of this haemagglutinin is associated with lipid and it is probably a lipoprotein (Stone, 1946 $a$; Chu, 1948).

The restriction of the range of sensitive red cells to 'lipid-sensitive' fowl red cells appeared to be a phenomenon peculiar to vaccinia and other poxvirus haemagglutinins (Burnet \& Boake, 1946; McCarthy \& Helbert, 1960). However, Grist (1960) described a haemagglutinin specifically associated with tissue infected with an enterovirus, the Coxsackie $\mathbf{A} 7$ virus, which will also agglutinate only vaccinia-agglutinable

* Present address: Department of Virology, Wright-Fleming Institute of Microbiology, St Mary's Hospital Medical School, London, W.2. 
fowl red cells. This Coxsackie A 7 haemagglutinin was shown to be particulate and separable from the infective particle. Unlike vaccinia haemagglutinin, the activity of the Coxsackie A 7 haemagglutinin appears not to be associated with lipid but with protein (Williamson \& Grist, 1965).

Although both haemagglutinins will agglutinate only 'lipid-sensitive' fowl red cells, differences in the chemical nature of the reactive sites of vaccinia and Coxsackie A 7 haemagglutinins suggested that they might attach to susceptible red cells by different mechanisms. This hypothesis has been investigated by comparative studies of the reactions of these haemagglutinins with susceptible fowl red cells.

\section{METHODS}

Viruses. The viruses used were the Evans strain of vaccinia virus and the 1034 strain of Coxsackie A7 (Grist, 1960); sometimes the Lee strain of influenza type B virus was also used.

Preparation of haemagglutinins. Extracts of suckling mouse tissue infected with Coxsackie A7 virus were prepared as described previously (Williamson \& Grist, 1965) and used without further treatment as Coxsackie A 7 haemagglutinin.

Stock suspensions of vaccinia virus passaged in chick embryos were used to inoculate the chorioallantoic membranes of 12-day chick embryos to give confluent lesions. Membranes were removed 48 or $72 \mathrm{hr}$ later and extracted with physiological saline by disruption of the infected membranes in a mechanical homogenizer. The extracts were clarified by low-speed centrifugation and the supernatant fluid used as vaccinia haemagglutinin.

The Lee strain of influenza type B virus was passaged in the allantoic cavities of 10-day chick embryos. The influenza virus haemagglutinin was obtained by harvesting infected allantoic fluid $48 \mathrm{hr}$ after inoculation.

Haemagglutinination and haemagglutination inhibition tests. The preparation of vaccinia-agglutinable fowl red blood cells (r.b.c.) and the performance of these tests in Perspex depression trays were described by Williamson \& Grist (1965). Haemagglutination inhibition tests were used routinely to test the specificity of vaccinia haemagglutinin preparations. The haemagglutinin specifically associated with vaccinia-infected tissue is inhibited by vaccinia antiserum but not by normal serum (Stone, 1946a).

Preparation of antisera. Cockerels were immunized by four intramuscular injections at weekly intervals of $1.0 \mathrm{ml}$. of an extract of suckling mouse tissue infected with Coxsackie A7 virus, emulsified with an equal volume of incomplete Freund's adjuvant. The fowls were bled 7 days after the final injection.

Vaccinia antisera were prepared similarly in fowls by injection with adjuvant of an extract of vaccinia-infected chick embryo chorioallantoic membrane.

Treatment of red cells. It was established in the early stages of these investigations that vaccinia-agglutinable fowl r.b.c. were rapidly rendered auto-agglutinable by even limited exposure to RDE, potassium periodate or proteolytic enzymes. This prohibited the quantitative assessment of the effect of treatment by direct use of these cells in haemagglutination tests. In order to overcome this problem, the following indirect procedure was adopted.

Washed vaccinia-agglutinable fowl r.b.c. were resuspended to $1 \%(\mathrm{v} / \mathrm{v})$ in dupli- 
cate serial dilutions of $\mathbf{5 . 0} \mathrm{ml}$. amounts of $0.0025 \mathrm{M}$-potassium periodate in physiological saline. Similar duplicate $1 \%(\mathrm{v} / \mathrm{v})$ r.b.c. suspensions were made in $0.01 \%$ trypsin, $0.1 \% \alpha$-chymotrypsin, $1 \%$ papain and Vibrio cholerae filtrate (Burroughs Wellcome Ltd.). The proteolytic enzymes were dissolved in phosphate buffer saline, 0.14 M-sodium chloride $+\mathbf{0 . 0 1} \mathrm{M}$-phosphate buffer $(\mathrm{pH} \mathrm{7 \cdot 2)}$. Papain was activated by addition of $3 \%(\mathrm{w} / \mathrm{v})$ cysteine hydrochloride. Vibrio cholerae filtrate was reconstituted as directed by the suppliers. Treatment with $\mathrm{KIO}_{4}$ was at $18^{\circ}$ for $1 \mathrm{hr}$; with proteolytic enzymes at $37^{\circ}$ for up to $6 \mathrm{hr}$; with $V$. cholerae filtrate at $37^{\circ}$ overnight. Controls included in each series consisted of r.b.c. at a similar concentration incubated at the appropriate temperature in the absence of the particular reagent. After treatment, the r.b.c. were deposited by centrifugation at $500 \mathrm{~g}$ for $5 \mathrm{~min}$. and washed three times with $\mathbf{0} \cdot \mathbf{8 5} \% \mathrm{NaCl}$. Periodate-treated r.b.c. were washed with $0.85 \% \mathrm{NaCl}$ containing $1 \%(\mathrm{w} / \mathrm{v})$ glucose.

One of the duplicate sets of treated r.b.c. was then resuspended in $\mathbf{1 . 0} \mathrm{ml}$. of a solution containing four haemagglutinating units of Coxsackie A7 haemagglutinin. The other set was resuspended in $\mathbf{1 . 0} \mathrm{ml}$. of a solution containing vaccinia haemagglutinin at a similar concentration. Mixtures, together with controls, were kept at $18^{\circ}$ for $2 \mathrm{hr}$ with resuspension of the r.b.c. at frequent intervals. After exposure to the haemagglutinins, the r.b.c. were deposited by low-speed centrifugation and the titre of haemagglutinating activity remaining in the supernatant fluids determined.

\section{RESULTS}

\section{Range of susceptible fowl red cells}

The sensitivity of washed r.b.c. from $\mathbf{1 7 2}$ Rhode Island Red fowls to vaccinia and Coxsackie A7 haemagglutinins was determined. Suspensions of r.b.c. were adjusted to $0.5 \%(\mathrm{v} / \mathrm{v})$ by using a haematocrit. Serial twofold dilutions of each haemagglutinin were made from stock preparations containing 16 haemagglutinating units when titrated with the same susceptible r.b.c. All dilutions were made in bulk before dispensing on to Perspex plates in order to make each dilution series strictly comparable. Results were read $2 \mathrm{hr}$ after the addition of $0.5 \%(\mathrm{v} / \mathrm{v})$ fowl r.b.c. suspensions and again after standing at $4^{\circ}$ overnight.

Of the 172 samples of fowl r.b.c. tested, $60 \%$ gave identical titres with both haemagglutinins, $17 \%$ gave a twofold lower titre and $17 \%$ gave a twofold or slightly higher titre with Coxsackie A 7 haemagglutinin than with vaccinia haemagglutinin. There was an eightfold difference between the maximal and minimal titres obtained with both haemagglutinins. The remaining $6 \%$ of the fowl r.b.c. tested were not agglutinated even by higher concentrations of either haemagglutinin. Insensitive r.b.c. were also obtained from 12 chick embryos which were tested.

The fowl r.b.c. used in the experiments reported here were equally sensitive to both vaccinia and Coxsackie A 7 haemagglutinins.

\section{Effect of physical agents on haemagglutination}

Temperature. Haemagglutination titres obtained with vaccinia and Coxsackie A7 haemagglutinins were similarly affected by the temperature at which the tests were made. Parallel tests showed a twofold increase at $37^{\circ}$ and a twofold decrease at $4^{\circ}$ as compared with titres obtained at room temperature $\left(15-18^{\circ}\right)$. The patterns of 
agglutinated r.b.c. at each temperature differed, however, in that vaccinia haemagglutinin gave a uniformly distributed shield pattern, whereas Coxsackie A7 haemagglutinin gave a more densely packed pattern of coarsely agglutinated r.b.c.

Electrolytes. Vaccinia and Coxsackie $\mathbf{A} 7$ haemagglutinins were dialysed overnight against isotonic solutions of glucose, $\mathrm{NaCl}, \mathrm{MgCl}_{2}, \mathrm{CaCl}_{2}$ or $\mathrm{Na}_{2} \mathrm{SO}_{4}$. Haemagglutination titres were then determined with the use of isotonic solutions for the preparation of $0.5 \%(\mathrm{v} / \mathrm{v})$ fowl r.b.c. suspensions. With both vaccinia and Coxsackie $\mathbf{A} 7$ haemagglutinins, haemagglutination was not detectable in the absence of electrolytes. Coxsackie A 7 haemagglutinin gave identical haemagglutination titres in each of the isotonic salt solutions. Identical haemagglutination titres were obtained with vaccinia haemagglutinin in isotonic solutions of $\mathrm{NaCl}$ and $\mathrm{Na}_{2} \mathrm{SO}_{4}$. Haemagglutination with the vaccinia haemagglutinin, however, was decreased 16 -fold in isotonic $\mathrm{MgCl}_{2}$ and was completely inhibited in isotonic $\mathrm{CaCl}_{2}$. Unlike Coxsackie $\mathrm{A} 7$ haemagglutinin, agglutination of susceptible fowl r.b.c. by vaccinia haemagglutinin was inhibited by the divalent cations tested.

In other experiments, vaccinia haemagglutinin of a known haemagglutination titre in $0.85 \% \mathrm{NaCl}$ solution was dialysed overnight against isotonic $\mathrm{CaCl}_{2}$. Susceptible fowl r.b.c. equilibrated to isotonic $\mathrm{CaCl}_{2}$ were added to the dialysed preparation and the mixture kept at room temperature for $2 \mathrm{hr}$ with resuspension of the r.b.c. at frequent intervals. The r.b.c. were then deposited by low-speed centrifugation and the supernatant fluid dialysed against isotonic $\mathrm{NaCl}$. Haemagglutination titres determined after dialysis indicated complete recovery of vaccinia hacmagglutinin in the supernatant. In control experiments with isotonic $\mathrm{NaCl}$ as the suspending medium, haemagglutinin was not detectable in the supernatant fluid following exposure to susceptible r.b.c. $\mathrm{Ca}^{2+}$ ions therefore prevented the adsorption of vaccinia haemagglutinin to susceptible fowl r.b.c. Further experiments established that $\mathrm{Ca}^{2+}$ ions similarly inhibited agglutination of susceptible r.b.c. by a $0 \cdot 4 \%(\mathrm{w} / \mathrm{v})$ suspension of lecithin prepared as described by Stone (1946b).

Effect of $p H$ values. Haemagglutination titres were determined at room temperatures in $0 \cdot 85 \% \mathrm{NaCl}$ buffered with citrate buffers $(\mathrm{pH} 5 \cdot 0-6 \cdot 0)$, phosphate buffers $(\mathrm{pH} 7 \cdot 0-8 \cdot 0)$ and glycine buffers $(\mathrm{pH} 9 \cdot 0-10 \cdot 0)$. Preliminary experiments had shown that both haemagglutinins and fowl r.b.c. were stable over these ranges. There were marked differences in the effect of the $\mathrm{pH}$ value of the diluent on the titres obtained with vaccinia and Coxsackie A7 haemagglutinins (Fig. 1). With Coxsackie A 7 haemagglutinin, maximal titres were obtained between $\mathrm{pH} \mathrm{5.0}$ and $\mathbf{8 \cdot 0}$ but there was a marked decrease in titre as the diluent became progressively more alkaline. Conversely, titres were minimal in acid diluents with the vaccinia haemagglutinin, maximal titres being obtained in the alkaline range. Titres obtained with vaccinia haemagglutinin were closely paralleled by those obtained with the lecithin preparation under the same conditions.

\section{Effect of treatment of forol red blood cells}

Vibrio cholerae filtrate. A receptor destroying enzyme (RDE) present in $V$. cholerae filtrate destroys the red cell receptors for influenza virus (Burnet \& Stone, 1947). Treatment of lipid-sensitive fowl r.b.c. with an RDE preparation under the conditions described destroyed their ability to absorb the type B influenza virus strain 
Lee, but was without effect on the receptors for the vaccinia and Coxsackie A7 haemagglutinins.

Potassium periodate. Although r.b.c. receptors for vaccinia and Coxsackie A7 haemagglutinins were destroyed by the highest concentration of periodate used $(0.0025 \mathrm{M})$, there were quantitative differences in the degree of receptor destruction at lower concentrations (Fig. 2). Thus, susceptible fowl r.b.c. treated with $0.001 \mathrm{~m}$ potassium periodate completely absorbed the Coxsackie A 7 haemagglutinin, whereas only $50 \%$ of the vaccinia haemagglutinin was absorbed. Untreated r.b.c. completely absorbed both haemagglutinins under the same conditions. These results

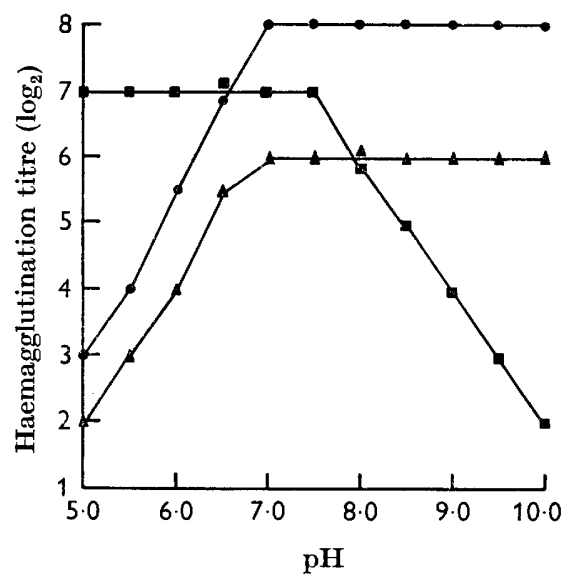

Fig. 1

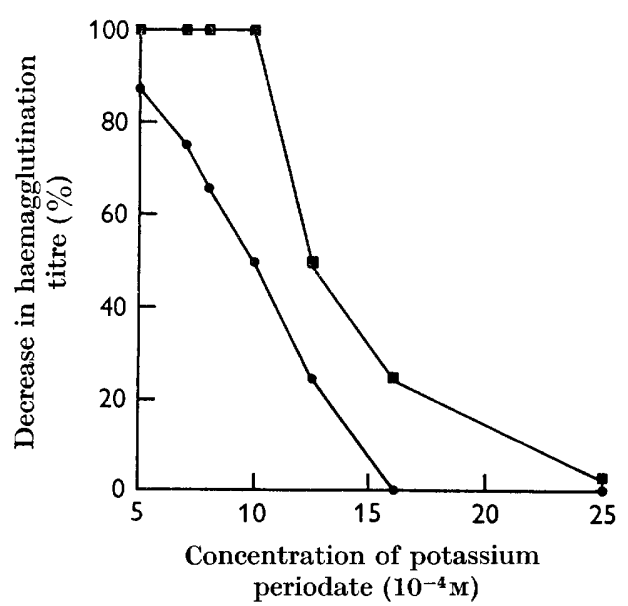

Fig. 2

Fig. 1. Effect of $\mathrm{pH}$ value on the agglutination of lipid-sensitive fowl red blood cells by vaccinia haemagglutinin, Coxsackie A7 haemagglutinin and a $0 \cdot 4 \%(w / v)$ lecithin suspension. -O, Vaccinia haemagglutinin; $\mathbf{D}-\mathbf{a}$, Coxsackie Ar haemagglutinin; $\mathbf{\Delta}-\mathbf{A}$, lecithin suspension.

Fig. 2. Absorption of vaccinia and Coxsackie A 7 haemagglutinins by potassium periodatetreated fowl red blood cells. - - Vaccinia haemagglutinin; - Coxsackie A7 haemagglutinin.

suggest that the r.b.c. receptors for vaccinia haemagglutinin are more sensitive to the action of periodate than those for Coxsackie A7 haemagglutinin.

Proteolytic enzymes. Papain and $\alpha$-chymotrypsin destroyed receptors for both vaccinia and Coxsackie A 7 haemagglutinins but quantitative differences were again established. Under the conditions described, treatment with $1 \%$ papain for $2 \mathrm{hr}$ completely destroyed the capacity of susceptible r.b.c. to absorb vaccinia haemagglutinin. Identically treated r.b.c., however, absorbed $75 \%$ of the Coxsackie A7 haemagglutinin to which they were exposed. Similarly, r.b.c. receptors for vaccinia haemagglutinin were completely destroyed by $0.1 \% \alpha$-chymotrypsin after $2 \mathrm{hr}$, but such r.b.c. retained the capacity to absorb 50\% of the Coxsackie A7 haemagglutinin. Extended treatment with papain or with $\alpha$-chymotrypsin rendered r.b.c. completely insensitive to Coxsackie A 7 haemagglutinin.

Treatment of r.b.c. with $0.01 \%$ trypsin up to $6 \mathrm{hr}$ did not diminish their capacity 
to absorb both haemagglutinins. Modification of the conditions of treatment by increasing the incubation period or the concentration of enzyme rendered the r.b.c. unsuitable for absorption experiments.

\section{Exclusion experiments}

Attempts were made to saturate susceptible r.b.c. with one of the haemagglutinins and then to determine whether such r.b.c. were capable of absorbing the second haemagglutinin. Saturation of intact r.b.c. with Coxsackie A 7 haemagglutinin was prevented by lysis of the r.b.c. by the haemolysin present in extracts of suckling mouse tissue infected with Coxsackie A7 virus (Williamson \& Grist, 1965). To overcome this difficulty experiments were made with stromata prepared by lysis of susceptible r.b.c. in distilled water. Such stromata were repeatedly resuspended in preparations of either the vaccinia or Coxsackie A 7 haemagglutinin. After thorough washing in $0.85 \% \mathrm{NaCl}$ solution at $4^{\circ}$, the stromata were resuspended in dilutions of the homologous haemagglutinin containing 4 haemagglutinating units. Failure to decrease the haemagglutination titre indicated complete saturation. After further washing, the stromata were resuspended in similar dilutions of the heterologous haemagglutinin. Neither stromata saturated with vaccinia haemagglutinin nor stromata saturated with Coxsackie A7 haemagglutinin showed any detectable absorption of heterologous haemagglutinin.

Stromata saturated with vaccinia or Coxsackie A7 haemagglutinin were also resuspended in dilutions of the influenza virus preparation containing 4 haemagglutinating units. Although control preparations completely absorbed the influenza virus haemagglutinin, there was no detectable adsorption to stromata saturated with vaccinia or Coxsackie A 7 haemagglutinin.

Table 1. Haemagglutination inhibition tests with vaccinia and Coxsackie A $^{7}$ haemagglutinins using homologous and heterologous immune sera

\begin{tabular}{|c|c|c|c|c|}
\hline \multirow[b]{3}{*}{ Haemagglutinin } & \multicolumn{4}{|c|}{ Serum titres } \\
\hline & \multicolumn{2}{|c|}{ Vaccinia } & \multicolumn{2}{|c|}{ Coxsackie A7 } \\
\hline & Normal & Immune & Normal & Immune \\
\hline Vaccinia & 32 & 1024 & 32 & 32 \\
\hline Coxsackie A7 & $<32$ & $<32$ & $<32$ & 512 \\
\hline
\end{tabular}

\section{Haemagglutination inhibition tests}

Differences in the serological specificity of vaccinia and Coxsackie Ar haemagglutinins were established by haemagglutination inhibition tests (Table 1). Homologous immune sera inhibited both haemagglutinins to high titre but there was no specific inhibition of either haemagglutinin by heterologous immune sera.

\section{DISCUSSION}

Quantitative differences revealed in the relative sensitivity of certain fowl r.b.c. to the two haemagglutinins suggest that although there is a close relationship between sensitivity to vaccinia and Coxsackie A7 haemagglutinins, there are quantitative differences in the capacity of some fowl r.b.c. to absorb these haemag- 
glutinins. Failure of Coxsackie A 7 haemagglutinin to agglutinate chick embryo r.b.c. indicates that red cell receptors for this haemagglutinin appear only as the fowls mature as previously described for receptors for vaccinia haemagglutinin (McCarthy \& Helbert, 1960).

The qualitative and quantitative differences in the effect of physical and chemical agents on the reaction of vaccinia and Coxsackie A7 haemagglutinins with susceptible fowl r.b.c. reflect differences in the physicochemical properties of both the haemagglutinins and the red cell receptors. Inhibition by divalent cations of the agglutination of r.b.c. by lipid-associated haemagglutinins has been previously reported with vaccinia haemagglutinin (Briody, 1951) and with the psittacosis haemagglutinin (Gogolak \& Ross, 1955). In the present study, only vaccinia and lecithin haemagglutinins were inhibited by either $\mathrm{Ca}^{2+}$ or $\mathrm{Mg}^{2+}$ ions. Physical and chemical studies have indicated that the activity of the Coxsackie A7 haemagglutinin is not associated with lipid but with protein (Williamson \& Grist, 1965).

The results of treatment of r.b.c. with $\mathrm{RDE}$, periodate and proteolytic enzymes suggest that the red cell receptors are probably mucoproteins but distinct from myxovirus receptors (Andrewes, Bang \& Burnet, 1955). Quantitative experiments indicate that, if the receptors are chemically similar, there are more receptors for the Coxsackie A 7 haemagglutinin than for the vaccinia haemagglutinin. Conversely, if there are the same number of receptors for each haemagglutinin, it may be argued that the receptors are chemically different. Attempts to resolve the relationship between the receptors by saturation experiments gave equivocal results and suggest only that there may be a close spatial proximity between the receptors for the two haemagglutinins. However, either interpretation of the quantitative experiments points to a distinction between the receptors for vaccinia and Coxsackie A 7 haemagglutinins.

Previous studies have shown that there are differences in the chemical nature of the red cell receptors for the haemagglutinins in the main groups of viruses (Klenk \& Lempfrid, 1957; Buckland \& Tyrell, 1963; Philipson et al. 1964). In addition to chemical differences (Williamson \& Grist, 1965), vaccinia and Coxsackie A7 haemagglutinins have been shown to be serologically distinct. Both qualitative and quantitative differences have been established in the reaction of these haemagglutinins with susceptible fowl r.b.c. It is concluded that these results indicate that, although closely linked, there are separate red cell receptors for vaccinia and Coxsackie A 7 haemagglutinins.

I wish to thank Professor N. R. Grist for his close interest in this work and Mr T. Miller for his valuable technical assistance. I am also indebted to Mr A. F. G. Smith (Ministry of Agriculture and Fisheries Veterinary Laboratory, Lasswade) for the collection of the fowl blood samples. This work was supported by a grant from the National Fund for Research into Poliomyelitis and other Crippling Diseases and was done during the tenure of the Sir Maurice Bloch Medical Research Fellowship. 


\section{REFERENCES}

Andrewes, C. H., Bang, F. B. \& Burnet, F. M. (1955). A short description of the myxovirus group (influenza and related viruses). Virology $1,176$.

Briody, A. (1951). A 'unitarian' view of vaccinia haemagglutinin. Yale J. Biol. Med. 24, 1.

Buckland, F. E. \& 'Tyrell, D. A. J. (1963). A comparative study of virus haemagglutinins. The stability of haemagglutinins and red cell receptors to certain chemical and physical treatments. J. gen. Microbiol. 32, 241.

Burnet, F. M. \& Bonke, W. C. (1946). The relationship between the virus of infectious ectromelia of mice and vaccinia virus. J. Immunol. $53,1$.

Burnet, F. M. \& Stone, J. D. (1946). The haemagglutinins of vaccinia and ectromelia viruses. Aust. J. exp. Biol. med. Sci. 24, 1.

Burnet, F. M. \& Stone, J. D. (1947). The receptor destroying enzyme of $V$. cholerae. Aust. J. exp. Biol. med. Sci. 25, 227.

CHU, C. M. (1948). Studies on vaccinia haemagglutinin: some physicochemical properties. J. Hyg., Camb. 46, 42.

Clark, E. \& Nagler, F. P. O. (1943). Haemagglutination by viruses. The range of susceptible cells with special reference to agglutination by vaccinia virus. Aust. J. exp. Biol. med. Sci. 21, 103.

GoGolak, F. M. \& Ross, M. R. (1955). The properties and chemical nature of psittacosis virus haemagglutinin. Virology $1,176$.

Grist, N. R. (1960). Isolation of Coxsackie A7 virus in Scotland. Lancet, i, 1054.

KLENK, E. \& Lemprrid, H. (1957). Über die Natur der Zellreceptoren für das Influenza virus. Z. Physiol. Chem. 307, 278.

McCarthy, K. \& Helbert, D. (1960). A comparison of the haemagglutinins of variola, alastrim, vaccinia, cowpox and ectromelia viruses. J. Path. Bact. 79, 416.

Neff, B. J., Ackermann, W. W. \& Preston, R. E. (1965). Studies of vaccinia haemagglutinin obtained from vaccinia infected tissue. Density gradient centrifugation and electron microscopy. Proc. Soc. exp. Biol. Med. 118, 664 .

Philipson, L., Bengtsson, S., Brishammar, S., Svennerholm, L. \& Zetterqvist, Ö. (1964). Purification and chemical analysis of the erythrocyte receptor for haemagglutinating enteroviruses. Virology 22, 580.

Stone, J. D. (1946 $a$ ). Inactivation of vaccinia and ectromelia virus by lecithinase. Aust. J. exp. Biol. med. Sci. 24, 191.

Stone, J. D. (1946b). Lipid haemagglutinins. Aust. J. exp. Biol. med. Sci. 24, 197.

Willitamson, J. D. \& Grist, N. R. (1965). Studies on the haemagglutinin present in Coxsackie A7 virus-infected suckling mouse tissue. J. gen. Microbiol. 41, 283. 